\title{
STYLE OF PERFORMING THE FLUTE CONCERTO BY JOSEPH BOUDIN DE POMERTE (1755-1689) J.B.DE BOISMORTIER
}

\section{Nahla Ali BAKIR *}

Faculty of Music Education, Helwan University, Egypt

\begin{abstract}
Arts play a Kira role in developing a person's talents with the experiences and skills he gains in general, music in particular, and practicing different arts refining and refining behavior and gaining the individual the ability to taste and integrate with the surrounding world so that he has the ability to veto, judge and evaluate, and he can distinguish between the beautiful and the ugly, which is reflected in his personality and emotion. It achieves the psychological balance of the human being, it is a purposeful message and it is a tool for communication between peoples and cultures across generations and times and contributes to highlighting the positive energy and transforming the person into an effective product capable of distinguishing all that is beautiful and upscale to serve and promote society, and art is an educational means for developing creative thinking, and gaining awareness of social and political issues Through the consolidation of many values such as equality, freedom, justice, democracy and a call for openness while preserving the national identity, historical roots and civilization, and in order to learn the new, culture must be acquired from previous civilizations and generations, and by exposure to the history of the development of the concerto template of flute in the Barrak era in different countries, which formed an important role in the shapes Musical, orchestral, enriched or even literature Rextra in general and deity in particular, through the flute concerto by Josef Bodine de Pomerte. J. B. de Boismartier, which is considered one of the treasures of the era, which was the beginning and basis for all our progress in different musical forms and compositions.

Keywords

Style, performing, the flute concerto, Joseph Boudin de Pomerte, J.B.de Boismortier.
\end{abstract}

\section{Introduction}

Upon exposure to flute literature, we will find that there was no music for flute before the year 1500 in particular, as the change of style in the middle of the 18th century was not fixed from one country to another and as a result of the structural composition of the transverse flute at that time and was assigned the role of accompaniment within another group of instruments in the century 18 It was only after the modifications that Hotteterre added to it that a single agency appeared in the period between 1660-1670, and the new flute acquired an important position at the end of the 18th century, and this was the beginning of the golden age of the flute machine. The popularity of the machine increased greatly, and many artists in all countries in general and France in particular responded to present a different outcome for the instrument according to the developments in the instrument, the different musical forms and the audiological requirements of the audience and the development of the Concerto template, as it was the first French version to use the title of Concerto. (1689-1755), who was the first to introduce the term concerto for French music.

\footnotetext{
*Corresponding author: info@music.helwan.edu.eg
} 


\section{Research Problem}

The research problem is concentrated in that the style of performing the flute concerto for a number of five flutes at Bomartier, which combines skillful techniques and the highest control in matching the correct tuning (Intonation), which is tuning the instrument's tones with itself and between it and other instruments in some tones, and the top of the control in matching the correct tuning. It is the tuning of the instrument's tones with other machines, which have not been exposed and have not received sufficient attention from the students, and which require from the learner technical maturity that helps him focus and realize the nature of work for that period.

\section{Concerto}

The term concerto is derived from the Latin word concertare, which means debate or competition and also means sharing a performance with another person. Three moves of an orchestra and a solo instrument to compete with.

\section{Solo performance}

It is a solo or instrumental performance, and in it the concerto refers to the performance of an individual while the rest of the orchestra accompanies it, with the need to perform lightly and softly to give the solo performance the opportunity to shine and clarity.

\section{Articulation Techniques}

It is the art or method of coordinating recitation (pronouncing word exits) and this applies to the methods of pronunciation in the flute, as it is similar to what happens in the method of pronouncing the exits of linguistic words.

\section{Intonation Matching}

It is the sound of the tones correctly (the fixed frequency of each tone), which is either between the instrument and itself and between other instruments in some tones or between the instrument and other tuning instruments.

\section{Part One:}

\section{Brief on the life of Boudin Pomerte (1689-1755):}

He is a French composer who spent his childhood in Thionville and then went to Metz 1700, and in 1724 he deserved the royal privilege to write and publish his works which stopped with his death, and in 1745 he was the conductor of the Philharmonic Orchestra.

- His writings are considered among the treasures of music that influenced Baroque music and contributed to the expansion and enrichment of the flute's compositions. Many of his compositions addressed to amateur groups that only require an average of technical skill and various variations of mechanical assemblies, and the evidence for this is the flute and volute 
sonat without bass number (51), and the sonatas For a number that fagot and 4 flute.

- As for his mechanical compositions, he assigned roles equally between machines, which consist of a series of simulations. While at that time the harpsichord was always dominant and dominant over the melody among the rest of the composers, its initial prescriptions for the two instruments were complementary to each other, such as a compiler sonnet (21) for keyboard and flute.

Pomorte adopted the three movements always favored by Italian authors and wrote many concerts for many different machines, such as his concerta for five flutes without a bus, classified No. (15) for the year 12, and he wrote many cantats and motets full of skills, which is a mixture of Italian and French elements in the formation of a triad dominant in The lyrical part, while the text of the cantat is unknown to him, fully expresses the period and was often using short formulas, and after the year 12 he began to follow the prevailing fashion and abandon the kantata, and wrote the solo performances within

The death in the Italian style, he composed many operas and contributed to the development of verbal texts and wrote many educational works, including his music of ingenuity and talent.

\section{The development of the flute concerto in the Baroque era:}

- Afternoon of Baroque is divided into three periods, the first from (1580-1630), the middle from (1630-1680) and the last or late from (1680-1730), and upon exposure to the literature of the flute, we will find that the first and middle periods did not bear fruit to a large extent because the transverse flute It did not develop until the middle of the middle period, and the single-key flute did not have a prominent position until after 20 years of the late period, the flute rose and became its place in the period between (1660-1760) and there was no music for flutes before the year 2000 in particular. Whereas, the change of style in the middle of the eighteenth century was not fixed from one country to another and as a result of the structural composition of the transverse flute at that time, it was assigned the role of accompaniment within another group of machines in the seventeenth century, and it did not appear as a single instrument until after the modifications that Hotteterre added to it in the period between (1660-1670) and the new flute became important at the end of the 18th century, and this was the beginning of the golden age of flute.

- The flute took its place first in France and then Germany, during the 18th century. The flute became a popular instrument in England after the coronation of George I, as it was exported from France to England and then appeared in Italy later around 1715 and it took about 10 years to take its place. The visit of Kavans helped Quvantz of Venice in 1726 persuaded Vivaldi to incorporate the flute into his compositions as an instrument of its potential.By 1761, the 
transverse flute was used by professional musicians and the recorder was used only for entertainment by amateurs and those who did not have sufficient skill to play the flute efficiently. The development of the flute concerto in the era of Baroque in different countries are as follows:

\section{France:}

- The one-key transverse flute appeared for the first time in an orchestral agency in 1681 and was used in numerous operas 1690 , and the popularity of the flute has increased greatly and the music market demands the presentation of many musical compositions. God the French artists have responded quickly, from which the music has spread and a delegation has affected the audio requirements of these places on The quality of the music, as the echo of churches such as Saint Mark in Venice required a somewhat slow musical rhythm, but it suggested the presence of dynamic and reverberating effects, which allowed the Concerto Ripieno (a small group that does the work of the large group) to appear in the concerto. Concerto gross0 appeared first, then the solo concerto. The Italian Baroque era is one of the important developments of the middle of the Baroque era, which was applied to woodwind music in general and flute.

- Then after that the instrument's popularity spread in Paris, the Italian influence increased in France, and the concerto became the favorite of the orchestral soloist and influenced by the Italians. Lestro Armonico published No. (3) for Vivaldi in Amsterdam (1911), which achieved tremendous success in Paris and likewise knew the Albinoni concerta in France, starting from (18). The Vivaldi Concerto 18 for the flute, entitled Four Seasons, was prepared, which is a set of 4 cartridges for the Violin machine.

- The flute played an important role in accepting the template of the concerto in France and it was the first French edition to use the title of a concerto. Its concerto for five transverse flute machines accompanied the bus was composed by Joseph Bodin de Bismortier (1689-1755) classified No. 15 in the year 19, as he was the first to introduce the term Concerto for French Music in Concerto (cello, viola or fagot), compiled No. 26 in 18.

Baumorte published several other concocts in the following year, so he then presented a set of concerts to Michel Corrette, and Pomerette's three movements followed the shape of the Italian and there was a modification of the Solo-Totti, but he did not completely escape from its first origins as the melodic material seemed to be more French than Italian Where he was considered the traditional Italian Ripieno Ganja in his concerto, for example Classified No. 3 General (18) which was recorded for Flute, Violin, Papua, Fagot and Bus, Concerto No. 2 of the same year for the number of 7 flutes, and Concerto No. 68 of the year 18 entitled Noelson Concerto a 4 
Parties which Recorded for violin, flute and opa, Gali Christophe Naudatu 1690-1762 was a contemporary French flute player of Plavit and Pomerite and he composed brilliantly between (1726-1752) and his main contribution was in the second publication of a full-set print of 6 solo concerto in France around 1735-1737 It was modeled after the first group of Vivaldi, ranked 10 in the year 1950, which is quite similar to the Italian style, all in three movements (fast - fold - fast) based on the Ritor principle nello with modification and decoration of the slow middle movement in the French style and the first and last parts, rapid and successive movements like the Vivaldi style with the use of strong synergies, Jean-Marie Leclair (16971764) is known as the founder of the French Violinna school and has made active contributions to the bear hearts and has been able to succeed perhaps because of his association with Plavia in the Concert Spiritup to compose between French and Italian forms and between the usual styles of performance, Leclerc used the various technical methods of the Italian Violin School (such as double, triple and quadruple stops, double tremors, left hand vibration, careful selection of the variety of bow strokes) and where the Italian Violinna school was known for its complex improvisational decorations and according to the Italian style Leclerc determined that one of the Violin Concerto No. 3, compiled No. 3 in the year 19, could be performed on the flute or oboe. His concerto leaves no doubt that he was fully aware of the works of Vivaldi, Correlli and Albinoni, a clear influence in preparing and presenting melodic sentences for Totti's performance on the flute concerto and considered the middle movement. Great model for French melodies.

\section{Michel Corrette}

Michel Corrette 1709-1795 presented the first solo concertos for flute in the year 18 and he embodied the popular (air) singing style of this period and includes 25 comedy concerts 17321760 using religious melodies and Christmas tones in Concertos de, Concertos Spirituels Noel's for the flute His works illustrated a number of progressive and earlier features of classicism, such as effective contrast, descent, and repetition of bass tones and rhythms with delay to pitch. The French flute school entered a new third phase in the 1740's in the 1740's, and it was at the beginning of the end, and the life of concerts and fresh flute tones continued at the hands of Hauter, Corette and Pomerete. The flute occupied a new place in the orchestra, especially after entering the stage of development and improvement in the capabilities of the instrument. The work of the flute in the middle of the 18th century in France reflected the musical tendency of the era, where the style of Rococo appeared, and the authors tried to experiment with the methods of playing notes with succession and succession, influenced by the new symphonic style and the use of the harmonic rhythm Slowness, wide range of notes, use of motifs, the 
history of solo performances began to decline, and the flute began its era. The new orchestral agency.

\section{Italy:}

In Italy, flute had a presence, although not of importance in France, and the Italian use of wind instruments dates back to the 14th century. This matter greatly increased in the orchestral concerto, and the concerto was the means for the distinctive Italian contribution to the flute literature in the Baroque era and in chamber music, Italians did not care about wind instruments compared to In the French, the transverse flute did not appear in Italy until between (1210120), and it did not become popular until another ten years later when Kavans traveled to Italy in 1974, and the flute first appeared in an Italian concerto as a member of the Scarlatti Concerto, entitled Twelve Simfonie di concerto grosso in the year 1910.

The most important Italian composer of this era was Antonio Vivaldi 1678-1714, who composed more than (500) concerto, including more than (50) for a single flute.

- The most important contribution of Vivaldi was the development of the concerto, from which the flute benefited, and he is referred to as the inventor of the fast movements in the Ritornello formula, in which it is played by the entire orchestra and appears in various keys with modification with the free syllables of the single instrument as explained by the method of fast, slow, fast form to organize the movements of the concerto. Instruments are a lot in the complete works of Vivaldi, and they range from a single concerto with the orchestra (350) of them (20) for the flute, and between (40) for the Latins with an orchestra, (40) concertos, including one for the two flutes, and a combined concerto for three single instruments or more of them (20). Number (3) flutes in addition to (20) a chamber music concerto that lacks the orchestral Ripieno, which is the gathering for the solo performance of the Tutti composition, and the flute appears in almost all of them.

- Among the works of Vivaldi Concerto and Flute is classified 10 years ago entitled La tempest di Mare, the goldfinch Cardellino and Le Notte, and the second movement, Fantasmi, which includes forms of open synergies, fast paced and successive stairs.

- Although Vivaldi occupied a major position in the Baroque era, many of his countrymen did a lot in flute literature, such as Alessandro Marcello (1684-1750, who is from Venice, Italy, and wrote a set of 6 La Certa concerts (harp published in (12)) which is in style Vivaldi borrowed the title from the verse (12) for his teacher, and his works were characterized by the open positions of the contours in the orchestra. 1692-1736 Giuseppe Tartini - an Italian violinist, presented a number concerto for flute, using the Vivaldi style, but with the use of the solo performance more extensively than Vivaldi, he paid attention to the louder sounds and 
emphasis on sentences in keeping with the pre-classical style of composition. The Italians used different motifs from the French, so instead of decorating the melody to make it elegant and beautiful, they made it more dramatic, rich in antics, and technical in general, less graceful and beautiful, with pronouncements strongly explained. . Pretro Antonio Lo Catelli (1695-1764) wrote Concerto Grosso Compiler 1 in 1971, with a glimpse of the first classical style, which illustrates Correlli's conservative style. Giovanni Batista Sammartini 1700-1775 The flute has many forms, including 6 a single concerto dating back to the mid-sixties of the 18th century giving the impression of classical chamber music, and in some of them the flute approaches the new role of the instrument in the classical symphony.

\section{Results}

After completing the musical analysis performed by the researcher of the research sample, she reached the following results:

\section{Melody}

1. Baumourtet relies heavily on the melodic exchange between sounds in the form of dialogue.

2. Entering the main melody first with one or two sounds, then entering the rest of the sounds.

3. Magnify the melody and diversify it by displaying a bending part, its upside down, unified performance, and photography.

4. The highest ladder in which to perform is the large scale of Mai, and this is due to the nature of the machine at this stage.

5. There is no harmony at that stage, and the bass line is the integration of sounds by means of horizontal and polyphonic combinations in a simulated form, and the side-tuned melodies are tone versus tone and vertical homophonic combinations.

\section{Rhythm}

6. Using simple rhythms and using bass tones on the time unit to sense time. Expression:

7. The expressive aspect has expanded to include a great diversity between strong and weak performance and the gradation between them to suit modern machines. Rhythm and Pronunciation:

8. Use simple rhythms and articulation techniques in proportion to the melodic movement that did not go beyond broken tongue strokes, small melodic arcs, individual strokes of the tongue, and extended notes.

\section{Recommendations}

1. Paying attention to teaching such works and emphasizing the knowledge and study of the stages of development of the concerto in the Baroque era and its skies, and all that it needs in terms of maturity, comprehension, and ingenuity in matching the correct tuning. 


\section{References}

1- Ahmed Bayoumi: The Musical Dictionary, First Edition, The Egyptian Opera House, Offset Press, Eastern Advertising Company, Cairo in the year 19.

2- Amr Mohsen El Sebaei, common problems associated with the most basic elements in teaching the art of playing the flute, research publication of the Faculty of Music Education Helwan University - Cairo, 19 AD.

3- Cliff Eisen: "In The New Grove's dictionary of music and musicians", second edition, Ed., Macmillan.Pub., London, 1980.

4- Davis, Marlyn Kornrich: "Music Dictionary", Faber \& Faber Limited, London, 1957

5- Philippe Lescat: "In The New Grove's dictionary of music and musicians", second edition, Ed., Macmillan Pub., London, 1980.

6- Randal, Don Micheal: "The New Harvard dictionary of Music", Harvard University press, Cambridge, 1986.

7- Toff, Nancy: "The Flute Book", Oxford University, press, second. Edition, Newyork, 1996. 8- Kanaan Ghadhban Habib AL-SHAWHANI, OPTIMISM AND PESSIMISM AND THEIR RELATIONSHIP TO THE CHARACTERISTICS OF INTERMEDIATE SCHOOL FEES, International Journal of Humanities and Language Research, Vol. 1, No. 2, 2018, pp. 22-26.

Received: January 17, 2019

Accepted: March 26, 2019 